UDC 621.43.056; 629.3

T. N. Kolesnikova ${ }^{1}$, Cand. Sc. (Tech.), orcid.org/0000-0002-8568-4688,

O.P.Sakno ${ }^{1}$, Cand. Sc. (Tech.),

orcid.org/0000-0003-4672-6651,

O.V. Lysyi², Cand. Sc. (Tech.),

orcid.org/0000-0002-7389-1161,

N. O. Velmagina ${ }^{1}$, Cand. Sc. (Phys.-Math.),

orcid.org/0000-0002-5584-3748
DOI: $10.29202 /$ nvngu/2018-3/7

1 - Prydniprovs'ka State Academy of Civil Engineering and Architecture, Dnipro, Ukraine, e-mail: tnk1403@ukr.net; sakno-olga@ukr.net; velmagina@yandex.ua

2 - Military Academy, Odesa, Ukraine, e-mail: lenafox107@ gmail.com

\title{
MATHEMATICAL MODELING OF THE OPERATING PROCESS OF THE ENGINE AND MEANS OF INCREASING SERVICE LIFE OF VEHICLES
}

Purpose. Modeling of the engine intake process with a non-traditional power mechanism and improvement of maintenance system and repair of vehicles by adjusting maintenance modes.

Methodology. During the simulation of the intake process of the gasoline engine, theoretical positions based on the fundamental theory of thermal motors, thermodynamics and hydraulics are used. The work of a non-shaft engine was investigated with usage of calculation-theoretical research methods. Experimental studies of the change in the life-cycle of trucks during the exploitation operation were carried out using simulation numerical modeling and road tests at the automobile enterprise. The methods of theory of probability and mathematical statistics, reliability theory are used.

Findings. The mathematical model of the engine intake process with an unconventional power mechanism allows us to evaluate the measures aimed at optimizing the design of the engine and increasing its fuel efficiency. It is simpler, less labor consuming and requires less machine time for calculations compared to conventional models. Algorithms of analysis of truck failures and determination of their rational modes of maintenance (on the example of Volvo vehicles) have been projected. The economic effect of innovations involves reducing operating costs per unit of performed transport and increasing profits.

Originality. The mathematical model of the working cycle of the engine is specified in the part of development of the model of the intake system, which takes into account kinematics of the engine and an alternating degree of compression, which increases its fuel efficiency by $10 \%$.

Practical value. Measures are developed for controlling the technical condition of the main parts of trucks and their maintenance, taking into account the actual state of the vehicles, which allowed increasing the probability of predicting $10 \%$ of malfunctions. The usage of these measures can increase the technical condition of the mining industry.

Keywords: non-shaft engine, intake system, working cycle, maintenance of vehicles

Introduction. The main trends in modern automotive industry are the increase in liter capacity, improvement of environmental parameters and the increase in fuel economy of piston engines.

Current engines with a crank-shaft mechanism are insufficiently economical. With improving their fuel efficiency, the design of engines is significantly complicated.

Above described requirements correspond to engines of nonconventional design, among which the engine with a non-shaft crank mechanism with variable compression can be distinguished.

The work of engines with an unconventional power mechanism and a variable compression mode in partial modes has been hardly investigated. The partial modes are significant part of the total engine running time. Therefore, it is impossible to predict the fuel consumption in the operation of the engine on partial modes. Modeling of the intake system of the engine with the unconventional power mechanism and the variable com-

(C) Kolesnikova T. N., Sakno O. P., Lysyi O.V., Velmagina N. O., 2018 pression mode on partial modes is an integral part of the calculation.

In addition to improving the fuel efficiency of the engine, increasing the efficiency of the operation of vehicles depends on the rational maintenance (technical service). The high-quality maintenance, which is done in time, is the guarantee of reliability and low operating costs for long-term operation of vehicles.

Aforementioned information points at the relevance of the topic - the need for research on the economic efficiency of a non-shaft engine in terms of its utilization in the road transport, especially in the mining industry. Based on the research on the vehicle service life, it is necessary to develop a new approach to efficient operation by adjusting the periodicity of the maintenance (technical service), taking into account the operating conditions.

Analysis of the recent research and publications. The constructions of engines with variable compression mode were engineered by constructors who were also engaged in the cooperation with companies as Ford, Mercedes-Benz, Nissan, Peugeot and Volkswagen. The 
engineers of research institutes and companies have received thousands of patents. None of these engines has undergone full-scale production, since the problem with vibration has not been resolved.

The engines with original kinematics are being explored now [1]. The author analyzes the equilibrium of the engine with variable compression and working volume. It is shown that the equilibrium of traversing mechanisms at moderate values of the number of cylinders of the engine is complicated with comparison to other known structures.

The research and the engineering works on the creation of an engine with a cranked spherical mechanism are being conducted in many countries [2]. From the analysis of works [1-3], we can conclude that the variable compression ratio is easier to implement using a non-shaft engine with a cranked spherical mechanism.

A method for modeling the working processes in the combustion chamber of the internal combustion engine had been developed. The method includes description of the preparation of a three-dimensional model of the engine combustion chamber, putting of a finite elemental grid, the problem of boundary conditions [4].

A method for simulation of thermal processes in a low power piston engine was developed [5]. Modern design packages were used for simulation of this process.

Diverse numerical simulations of the purge of the intake valve system of the piston engine system using a new implicit modification of the method of large frequencies were performed [6]. Recommendations for improving the flow characteristics of the gas exchange system of the classical engine were obtained.

However, in these works, there are no methods and results of the study taking into account the kinematics of an unconventional power mechanism of the engine with varying compression ratio.

With the development of vehicle designs, the maintenance of a proper level of their operational reliability remains relevant, especially in the case of trucks for the mining industry.

Modern constructions of vehicles require certain conditions for maintenance (technical service), which are recommended by the manufacturer [7]. Trucks work on difficult and mountainous road sections and on soft grounds, therefore their high level of technical condition requires adjusting modes and amounts (technical service).

Objectives of the article. The purpose of the work is to simulate the process of driving an engine with an unconventional power mechanism and to improve the maintenance system and auto service by adjusting the modes of maintenance.

To reach this goal, the following tasks were set:

- to simulate the engine intake process, to determine the total pressure loss in the engine intake system, taking into account the kinematics of an unconventional power mechanism;

- to develop an algorithm for adjusting the maintenance of vehicles taking into account the factors which influence the service life of their main parts;

- to evaluate the economic efficiency of the improvement of the maintenance system and repair of vehicles.
Refinement of the mathematical model of the engine intake process. The engine model is made up of three sub-models: intake system model, cylinder model and exhaust system model. One of these sub-modules of the engine is considered, namely, the model of the intake system, which consists of an air cleaner, a throttle valve, an inlet pipeline, a cylinder head, and an inlet valve.

Certain assumptions were made to compile the mathematical model. The pressure before the inlet valve is constant and equal to the average conditional pressure in the inlet line. The heat regime of fresh charge is steady. The temperature and charge density are constant. The flow of gas in the inlet of the engine is considered constant. In the inlet pipe on partial loads of the engine, the flow after the throttle valve is not restored. The pressure before the inlet valve is equal to the gas pressure in the inlet section of the throttle valve. It takes into account the loss of pressure in the air cleaner, the cylinder head and friction along the length of the pipeline. With a small pressure drop, the compressibility of gas can be ignored.

Taking into account the assumptions, the scheme of modeling of the engine intake system was compiled. The difference between the calculation process from the actual one is taken into account by the corresponding coefficients.

Engine intake system model. The calculation model of the intake system of the engine is shown in Fig. 1.

In the proposed intake system, there are three sections: the cross section $0-0$, with the air velocity taken as equal to zero $v_{0}=0$, the pressure is equal to the atmospheric $p_{0}$, section $1-1$ is taken before the inlet valve and the section $\mathrm{a}-\mathrm{a}$ is located at the end of the inlet.

The process of the inlet system is considered in the following formulation: the parameters of the fresh charge stream $p_{B}$ and $T_{B}$ before the inlet valve are determined, taking into account the load $\varphi_{d r}$ and the speed of the engine $n$.

Applying the equation of mass conservation, the heat exchange, the first law of thermodynamics and the state equation of gas according to known flow parameters in front of the inlet valve, the thermodynamic parameters and mass of the mixture in the engine cylinder have been determined.

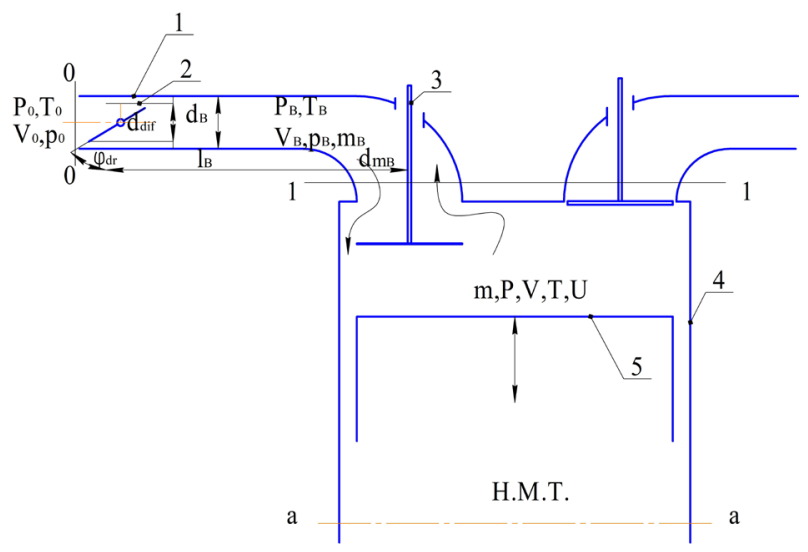

Fig. 1. Design model of the intake system of the engine:

1 - intake pipeline; 2 - throttle valve; 3 - intake valve; 4 -cylinder; 5 - piston 
The calculation of the parameters of a fresh charge in the inlet system is made according to known hydraulics formulas.

Temperature of mixture in the inlet line. Using experimental data, the temperatures of the mixture in the inlet line [8], which are approximated for modern engines depending on the speed and loading modes, dependences of the temperature change of the mixture before the intake valve were also obtained, taking into account the speed and loading modes of the engine

$$
T_{B}=T_{B}^{n} \frac{T_{B}^{d r}}{T_{B}^{n}},
$$

where $T_{B}^{n}, T_{B}^{d r}$ is temperature of mixture $(\mathrm{K})$ depending on the speed of the crankshaft $n\left(\mathrm{~min}^{-1}\right)$ and the opening angle of the throttle valve $\varphi_{t h}(\%)$, accordingly.

The temperature of the mixture from the frequency of rotation $n$ is

$$
t_{B}^{n}=77-\left(77-t_{B}^{N}\right) \cdot\left(\frac{1600+n}{1600+n_{N}}\right)^{\frac{1}{h}},
$$

where $t_{B}^{N}$ is the temperature of the mixture at nominal mode of the engine, ${ }^{\circ} C ; n_{N}$ is the nominal rotational speed of the crankshaft, $\min ^{-1} ; h$ is the exponent, $h=4$.

The mixture temperature is

$$
T_{B}^{n}=t_{B}^{n}+273.15 \text {. }
$$

The temperature of the mixture with depending on the size of the opening of the throttle valve (\%), is determined by the system of equations

$$
\left\{\begin{array}{l}
t_{B}^{d r}=85-\left(85-t_{B}^{N}\right) \cdot\left(\frac{\varphi_{d r}}{100}\right)^{\frac{1}{h_{1}}} \quad \text { when } \varphi_{d r} \leq \varphi_{d r}^{k} \leq 100 \% \\
t_{B}^{d r}=55-\left(55-t_{B}^{k}\right) \cdot\left(\frac{\varphi_{d r}}{\varphi_{d r}^{k}}\right)^{\frac{1}{h_{2}}} \quad \text { when } 0 \leq \varphi_{d r} \leq \varphi_{d r}^{k}
\end{array},\right.
$$

where $\varphi_{d r}^{k}=25 \%$ is the intermediate angle of opening of the throttle valve; $h_{1}=3.5 ; h_{2}=2$ is the exponent; $t_{B}^{N}$ is the temperature of the mixture at $\varphi_{d r}^{k},{ }^{\circ} C$; $t_{B}^{k}=t_{B}^{d r}\left(\varphi_{d r}^{k}\right)$

The temperature in $\mathrm{K}$ is

$$
T_{B}^{d r}=t_{B}^{d r}+273.15
$$

Lowering the temperature $T_{B}$ due to fuel evaporation in the inlet pipeline is not taken into account.

Pressure of the mixture in the inlet line. Losses of pressure at places $0-0$ and $1-1$ consist of losses from hydraulic resistance along the length of the flow and losses from local resistances.

Total pressure loss in the intake engine is

$$
\Delta p_{B}=\Delta p_{t r}+\Delta p_{d r}+\Delta p_{n o}+\Delta p_{r c}
$$

where $\Delta p_{t r}, \Delta p_{d r}, \Delta p_{n o}, \Delta p_{r c}$ are losses of pressure from hydraulic resistance, respectively in the pipeline, throttle, air cleaner and cylinder head, $\mathrm{Pa}$.
The friction pressure losses in the inlet pipe between the throttle valve and the section 1-1 are calculated by the Darcy formula [9]

$$
\Delta p_{t r}=\lambda_{i n} \cdot \frac{l_{B}}{d_{B}} \cdot \rho_{I n} \cdot \frac{v_{B}^{2}}{2},
$$

where $\lambda_{\text {in }}$ is the Darcy coefficient, which characterizes the resistance of flow through the length of the inlet line; $l_{B}$ is the length of the considered section of the flow in the inlet line; $d_{B}$ is the internal diameter of the inlet line; $v_{B}$ is the average per-section speed of the charge in the inlet pipeline; $\rho_{I n}$ is pre-determined average charge density at the considered section of the inlet pipeline.

Depending on the size of the throttle opening $\varphi_{\mathrm{dr}}$ and frequency of rotation $n$, the relative loading $\lambda_{N}$ is calculated by the formula

$$
\lambda_{N}=1-\left(\frac{100-\varphi_{d r}}{100-\varphi_{d r x x}}\right)^{m},
$$

where $m$ is the index of degree, which is determined by the dependence

$$
m=\left(m_{\max }-m_{\min }\right) \cdot\left(\frac{n_{\max }-n}{n_{\max }-n_{\min }}\right)^{a}+m_{\min },
$$

where accepted $m_{\max }=4.5 ; m_{\min }=2.041 ; n_{\max }=n_{\mathrm{dis}}$; $n_{\text {min }}=0.25 n_{N} ; a=4.5$,

where $n_{\text {dis }}$ is the distinct frequency of rotation of the crankshaft, $\min ^{-1}$.

The value of the local resistance $\xi_{d r}$, which is the function of the opening angle of the throttle valve, is determined by the Weissbach formula [18]

$$
\xi_{d r}=\frac{2 \Delta p_{d r}}{\rho_{0} v_{B}^{2}}
$$

where $\Delta p_{d r}$ is pressure loss in the throttle (from friction);

$$
\Delta p_{d r}=\Delta p_{k}-\Delta p_{n o}-\Delta p_{d i f},
$$

where $\Delta p_{\kappa}$ is discharging in the inlet pipeline, $\mathrm{Pa}$. Pressure loss in the air cleaner $\Delta p_{n o}$. Pressure loss in the air cleaner in partial modes is determined by the formula

$$
\Delta p_{n o}=\xi_{n o} \cdot \rho_{0} \cdot \frac{v_{n o}^{2}}{2},
$$

where $\xi_{n o}$ is the coefficient of local resistance.

$$
\xi_{n o}=\frac{2 \Delta p_{n o}^{N}}{\rho_{0} v_{n o N}^{2}},
$$

where $\Delta p_{n o}^{N}$ is pressure loss in the air cleaner at the nominal mode [10]

$$
\Delta p_{n o}^{N}=(0.05 \ldots 0.1) \cdot \Delta p_{t r},
$$

where $\Delta p_{t r}$ is total resistance of the intake line at nominal mode, $\mathrm{Pa}$.

According to the data [10]

$$
\Delta p_{t r}=(11.5 \ldots 20.4) \cdot 10^{3},
$$

where accepted $\Delta p_{t r}=18 \cdot 10^{3} \mathrm{~Pa}$. 
Based on the results of experimental studies of hydraulic resistance of elements of the intake system of different internal combustion engine (ICE) [1-3], it was adopted

$$
\Delta p_{r c}=\Delta p_{t r u b} .
$$

As it was shown by the analysis of experimental studies [1-3] of hydraulic resistance of the elements of the intake system of different ICE, the loss in local supports in all cases are greater than frictional losses. In this case of the partial pressure of the engine, where the loss of pressure in the throttle valve is a very essential indicator.

Modeling the system of maintenance of trucks taking into account the factors which affect the service life of their main parts. The algorithms were developed in the process of studying the service life of load-trucks of Volvo brand names at the LLC "Zenal" LTD (Odesa, Ukraine) [11] (Figs. 2 and 3).

Statistical analysis of the main parts of Volvo trucks (LLC “Zenal” LTD, Odesa) [12] allowed:

- establishing the rational frequency of maintenance;

- summarizing the results of processing information on the quality of parts, units, models of trucks of the same type;

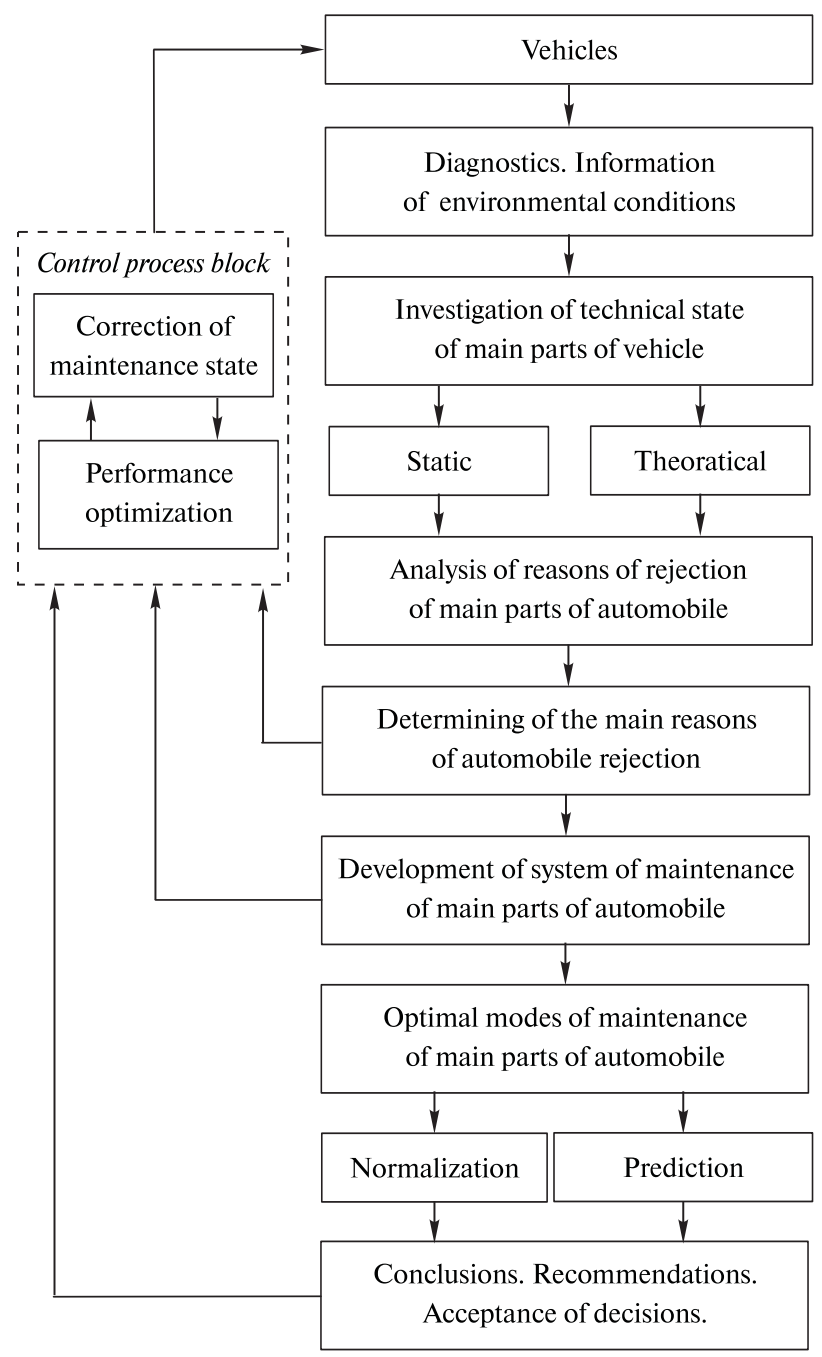

Fig. 2. Algorithm of analysis of rejection of vehicles (by the example of Volvo load-trucks)

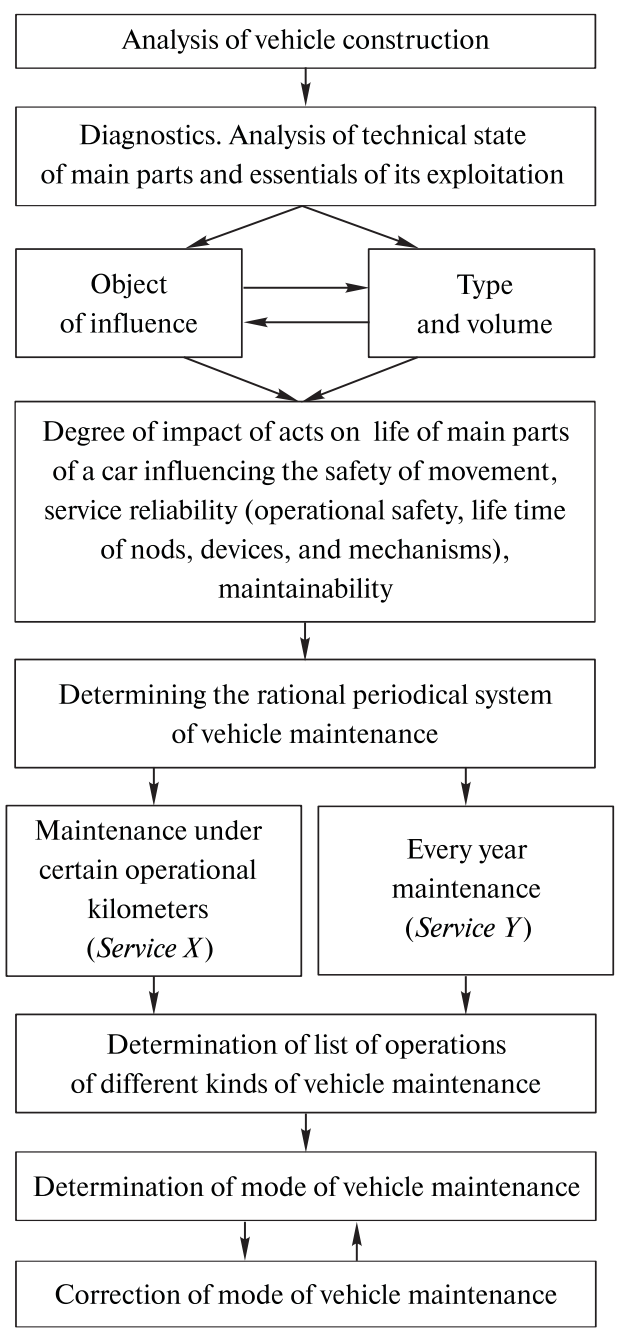

Fig. 3. Algorithm of projection of rational modes of maintenance of vehicles (by the example of Volvo loadtrucks)

- comparing actual quality indicators with the parameters which are contained in the design documentation of the truck model;

- analyzing the economic expenditures of eliminating defects of trucks;

- finding out details, assembly parts and combined parts, which limit the quality of trucks;

- determining the actual normalized quality indicators of trucks and their main mechanisms, parts, nodes.

The algorithm of failure analysis by the example of Volvo trucks during operation (Fig. 2) includes the following steps:

- collection, analysis of information on the refusal of aggregates by their types;

- identification of the most unreliable nodes, parts, and mechanisms;

- quantitative assessment of the reliability of nodes, parts, and mechanisms.

An algorithm has been developed to establish rational modes of maintenance and repair of vehicles (Fig. 3). On the basis of the algorithm, the main and core operations are represented mainly, which appear most often and have a great deal of complexity, determining traffic safety, reliability and economy of the vehicle. 
Advantages of using Volvo's adjusted truck schedule of technical service include:

1. Reduction of unplanned down-time of road trains.

2. Increasing of the period of failure maintenance of the auto enterprise.

3. Servicing of vehicles at branded service stations on the basis of scheduled dates.

4. Projection of maintenance and repair costs.

5. Use of Volvo's original spare parts.

6. Savings of funds of auto enterprise.

The results of the mathematical modeling of the engine intake process. The change in the temperature of the mixture of the inlet line before the inlet valve depending on the rotational speed $n$ according to the formula (1), is shown in Fig. 4, depending on the size of the opening of the throttle valve by the formula (2) - Fig. 5 .

The engine intake system model is based on the equations of pressure loss in the elements of the intake system. Intake system parameters are used for further calculations of compression, combustion, expansion and release processes.

With the accuracy of calculations, this mathematical model does not yield to known programs, but is much simpler, less labor-consuming and requires less machine time. The model makes it possible to evaluate the measures aimed at optimizing the design of the engine and increasing its fuel efficiency.

The estimation of economic efficiency of improvement of maintenance system and repair of automobiles. The economic effect of improving the maintenance and repair of Volvo trucks at the LLC "Zenal” LTD (Odesa) project involves reducing operating costs per unit of performed transport and increasing profits (Table).

As a result of improvement of the maintenance system and repair of trucks, the technical and operational parameters changed. In particular, the following items increased: the total operational kilometers per year (by 505 thousand km); car-hours of work (by 8212 hours); annual volume of transportations (by 5.9 thousand tons); cargo turnover (by 1487 thousand t-km).

The calculation of the expected economic effect involves further defining the deflection of the main performance indicators, mainly: the need and the amount of operating costs (total fuel costs, lubricants and maintenance materials; wearing, tearing and repair of automobile tires; maintenance and repair of vehicles) are changing.

Conclusions.

1. The engines with different kinematics of the power mechanism and the variable compression were ana-

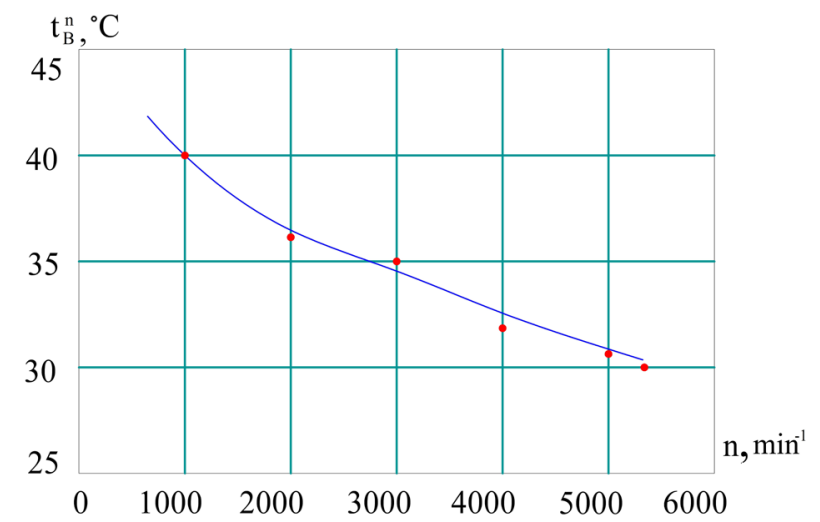

Fig. 4. Dependence of the temperature of the mixture of $t_{B}^{n}$

$\left({ }^{\circ} \mathrm{C}\right)$ on the frequency of rotation $n\left(\mathrm{~min}^{-1}\right)$ :

$$
\cdots \text { - experiment; - - calculation }
$$

$\mathrm{t}_{\mathrm{Bdr}},{ }^{\circ} \mathrm{C}$

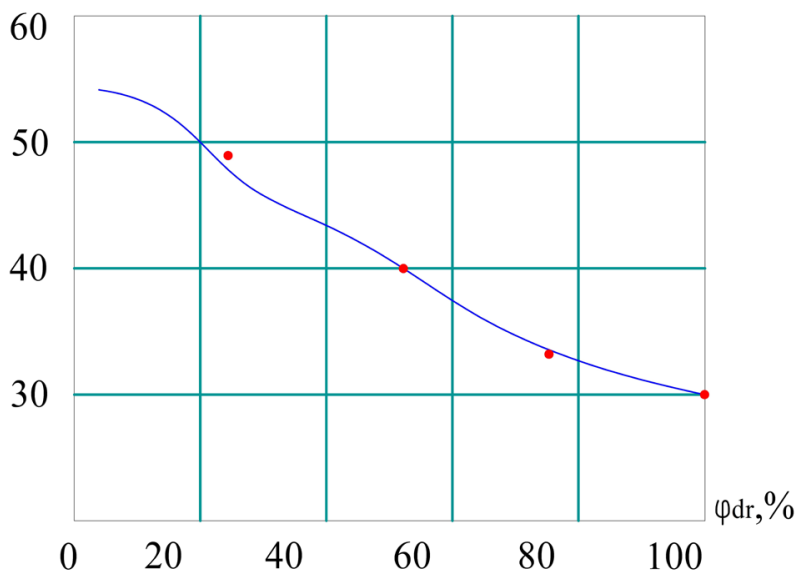

Fig. 5. Dependence of the temperature of the mixture of $t_{B d r}\left({ }^{\circ} \mathrm{C}\right)$ on the opening angle of the throttle valve $\varphi_{d r}$ $(\%)$ :

$\cdots$ - experiment; -- calculation

Table

Indicators characterizing economic efficiency of the improvement of the maintenance system and the repair of trucks by the example of Volvo trucks at the LLC "Zenal” LTD (Odesa)

\begin{tabular}{|l|c|c|c|c|}
\hline \multirow{2}{*}{ Indicators } & \multirow{2}{*}{$\begin{array}{c}\text { Conventional } \\
\text { signs }\end{array}$} & \begin{tabular}{c} 
Description of indicators \\
\cline { 3 - 5 } \\
the technical \\
readiness \\
coefficient
\end{tabular} & $\begin{array}{c}\text { after increasing } \\
\text { the technical } \\
\text { readiness } \\
\text { coefficient }\end{array}$ & $\begin{array}{c}\text { Change of } \\
\text { indicator by } \\
\%\end{array}$ \\
\hline 1. Annual volume of transportation, ton & $Q$ & 145876 & 151824 & 4.08 \\
\hline 2. Annual turnover, thousand ton-km & $W$ & 36469 & 37956 & 4.08 \\
\hline 2. Total operational kilometers of trucks per year, $\mathrm{km}$ & $L_{\text {Gen }}$ & 4545619 & 5050688 & 11.11 \\
\hline 3. Automobiles-hours of work of trucks, hours & Ahw & 73913 & 82125 & 11.11 \\
\hline
\end{tabular}


lyzed. On the basis of the analysis of the modeling of gas exchange processes, it is shown that methods for modeling the refractory engine inlet process taking into account its kinematics is absent at present time.

2. Dependences of temperature change before the inlet valve were obtained. The total pressure loss in the inlet system of the engine is determined by taking into account the kinematics of an unconventional power mechanism. The obtained model allows estimating measures aimed at optimization of engine designs and increase in its fuel efficiency.

3. The algorithms of analysis of automobile failures and the determination of rational modes of motor vehicles have been developed (by the example of Volvo loadtrucks). An improved system of maintenance and repair by adjusting the periodicity of technical influences by an example of Volvo trucks takes into account the factors that affect the life of the main parts.

4. The economic effect of improving the system of maintenance and repair of Volvo trucks at LLC "Zenal" LTD (Odesa) is the increase in the annual volume of transportation by $4 \%$ and the total operational kilometers of trucks by $11 \%$ per year.

Acknowledgement. We are grateful to the specialists of ADIDNTU and to Colonel Maslii O., Yevsyukov Y. and Director of LLC "Zenal" LTD Budyanskii O. for assistance in conducting experiments.

\section{References.}

1. Shuliak, M., 2014. Free-piston constructions - one of the most promising ways of improving power units of vehicles. Engineering of nature management, 1(1), pp. 17-23.

2. Luong, Hoang Quang and Dorohov, A., 2015. Kinematics and Dynamics of Conrod-free Mechanisms of Motion Transformation. Vestnik Of Astrakhan State Technical University [Series: Marine Engineering And Technologies], 3, pp. 79-87.

3. Kazimierski, Z. and Wojewoda, J., 2011. Double internal combustion piston engine. Applied Energy, 88(5), pp. 1983-1985. Available at: <http://www.sciencedirect.com/science/article/pii/S0306261910004447> [Accessed 20 February 2017].

4. Kurchatkin, I., Gorshkalev, A. and Tsapkova, A., 2016. Development and testing technique of modeling of working processes in internal combustion engines. International Research Journal, 6(48), Part 2, pp. 81-84. DOI: 10.18454/IRJ.2016.48.027.

5. Lukachev, S., Biryuk, V. and Gorshkalev, A., 2014. Using Ansys Fluent to Study Gas-Dynamic and Thermal Processes in Small-Sized Two-Stroke Engine. Science and Education of the Bauman MSTU, 12, pp. 416-425.

6. Grishin, Yu., Dorozhinsky, R. and Zenkin, V., 2012. Calculation improvement of the piston engine valve system characteristics. Proceedings of Higher Educational Institutions. [Machine Building] [pdf], 6, pp. 52-58. Available at: <http://izvuzmash.ru/articles/323/323. pdf $>$ [Accessed 14 May 2017].

7. Monteiro Tavares, C.M. and Szpytko, J., 2016. Vehicles Emerging Technologies from Maintenance Perspective. IFAC-PapersOnLine, 49(28), pp. 67-72.
8. Zhilkin, B., Shestakov, D. and Plotnikov, L., 2012. Some of characteristics of admission process of inlet process in supercharged internal combustion engines. Heavy Machinery, 2, pp. 48-51.

9. Morgunov, K., 2014. Hydraulics. Sankt-Petersburg: Publishing House Lan.

10. Sysoev, S., Gavrilov, A., Morozov, V. and Gots, A., 2012. Modeling for maximum pressure cycle of external characteristics of high-speed piston engine. Modern problems of science and education, 4. Available at: $<$ https://www.science-education.ru/ru/article/view? $\mathrm{id}=6581>$ [Accessed 10 March 2017].

11. Sakhno, V., Poliakov, V., Sakno, O. and Lysyi, O., 2015. The Research Of Service Life Of Major Unit Assemblies Of Road Train And The Expertise Of Expert Analysis Of Causes Of Changes Of Their Technical State. The National Transport University Bulletin: A Scientific and Technical Journal, 2(32), pp. 234-242.

12. Sakhno, V., Sakno, O. and Lysyi, O., 2015. To The Simulation Of The Road Train Maintenance And Repair System. Young Scientist [pdf], 5(20), Part 1, pp. 54-57. Available at: <http://molodyvcheny.in.ua/ files/journal/2015/5/12.pdf $>$ [Accessed 27 May 2017].

\section{Математичне моделювання робочого процесу двигуна та шляхи підвищення ресурсу автомобілів}

\section{Т. М. Колеснікова ${ }^{1}$, О. П. Сакно ${ }^{1}$, О. В. Лисий ${ }^{2}$, Н.О. Вельмагіна ${ }^{1}$}

1 - Державний вищий навчальний заклад „Придніпровська державна академія будівництва та архітектури“, м. Дніпро, Україна, e-mail: tnk1403@ukr.net; sakno-olga@ ukr.net; velmagina@yandex.ua

2 - Військова академія, м. Одеса, Україна, e-mail: lenafox107@gmail.com

Мета. Моделювання процесу впуску двигуна з нетрадиційним силовим механізмом і удосконалення системи технічного обслуговування (ТО) й ремонту автомобілів шляхом коригування режимів TO.

Методика. При моделюванні процесу впуску бензинового двигуна використані теоретичні положення, що базуються на фундаментальній теорії теплових двигунів, термодинаміки й гідравліки. Робота безшатунного двигуна досліджувалася з використанням розрахунково-теоретичних методів дослідження. Експериментальні дослідження зміни ресурсу вантажних автомобілів у процесі експлуатації проводились із застосуванням імітаційного чисельного моделювання та дорожніх випробувань на автопідприємстві. Використані методи теорії ймовірності й математичної статистики, теорії надійності.

Результати. Математична модель процесу впуску двигуна з нетрадиційним силовим механізмом дозволяє оцінювати заходи, що направлені на оптимізацію конструкції двигуна та підвищення його паливної економічності. Вона простіша, менш трудомістка й вимагає меншого машинного часу для 
розрахунків у порівнянні зі стандартними моделями. Розроблені алгоритми аналізу відмов вантажних автомобілів і визначення раціональних режимів TO (на прикладі автомобілів марки Volvo). Економічний ефект від нововведень передбачає зниження експлуатаційних витрат на одиницю виконаної транспортної роботи та збільшення прибутку.

Наукова новизна. Уточнена математична модель робочого циклу двигуна в частині розробки моделі впускної системи, яка враховує кінематику двигуна та змінний ступінь стискання, що підвищує його паливну економічність на $10 \%$.

Практична значимість. Розроблені заходи 3 контролю за технічним станом основних частин вантажних автомобілів і їх обслуговуванню з урахуванням фактичного стану дозволили підвищити ймовірність прогнозування несправностей автомобілів на $10 \%$. Використання даних заходів підвищує рівень технічного стану автомобілів гірничодобувної галузі.

Ключові слова: безшатунний двигун, впускна система, робочий цикл, технічне обслуговування автомобілів

\section{Математическое моделирование рабочего процесса двигателя и пути повышения ресурса автомобилей}

\author{
Т. Н. Колесникова ${ }^{1}$, О. П. Сакно ${ }^{1}$, А. В. Лысый \\ Н.А. Вельмагина ${ }^{l}$
}

1 - Государственное высшее учебное заведение „Приднепровская государственная академия строительства и архитектуры“, г. Днепр, Украина, e-mail: tnk1403@ukr. net; sakno-olga@ukr.net; velmagina@yandex.ua

2 - Военная академия, г. Одесса, Украина, e-mail: lenafox107@gmail.com

Цель. Моделирование процесса впуска двигателя с нетрадиционным силовым механизмом и усовершенствование системы технического обслуживания (ТО) и ремонта автомобилей путем корректирования режимов ТО.

Методика. При моделировании процесса впуска бензинового двигателя использованы теоретические положения, основанные на фундаментальной теории тепловых двигателей, термодинамики и гидравлики. Работа бесшатунного двигателя исследовалась с использованием расчетно-теоретических методов исследования. Экспериментальные исследования изменения ресурса грузовых автомобилей в процессе эксплуатации проводились с применением имитационного численного моделирования и дорожных испытаний на автопредприятии. Использованы методы теории вероятности и математической статистики, теории надежности.

Результаты. Математическая модель процесса впуска двигателя с нетрадиционным силовым механизмом позволяет оценивать меры, направленные на оптимизацию конструкции двигателя и повышения его топливной экономичности. Она проще, менее трудоемка и требует меньшего машинного времени для расчетов по сравнению со стандартными моделями. Разработаны алгоритмы анализа отказов грузовых автомобилей и определения рациональных режимов ТО (на примере автомобилей марки Volvo). Экономический эффект от нововведений предусматривает снижение эксплуатационных затрат на единицу выполненной транспортной работы и увеличение прибыли.

Научная новизна. Уточнена математическая модель рабочего цикла двигателя в части разработки модели впускной системы, учитывающей кинематику двигателя и переменную степень сжатия, что повышает его топливную экономичность на $10 \%$.

Практическая значимость. Разработаны мероприятия по контролю за техническим состоянием основных частей грузовых автомобилей и их обслуживанию с учетом фактического состояния, которые позволили повысить вероятность прогнозирования неисправностей автомобилей на $10 \%$. Использование разработанных мероприятий повышает уровень технического состояния автомобилей горнодобывающей отрасли.

Ключевые слова: бесшатунный двигатель, впускная система, рабочий цикл, техническое обслуживание автомобилей

Рекомендовано до публікації докт. техн. наук В.Г.Заренбіним. Дата надходження рукопису 18.04.17. 